\title{
Transmitted drug resistance, selection of resistance mutations and moderate antiretroviral efficacy in HIV-2: Analysis of the HIV-2 Belgium and Luxembourg database
}

Jean Ruelle ${ }^{1}$, François Roman ${ }^{2}$, Anne-Thérèse Vandenbroucke ${ }^{1}$, Christine Lambert ${ }^{2}$, Katrien Fransen ${ }^{3}$, Fedoua Echahidi ${ }^{4}$, Denis Piérard ${ }^{4}$, Chris Verhofstede ${ }^{5}$, Kristel Van Laethem ${ }^{6}$, Marie-Luce Delforge ${ }^{7}$, Dolorès Vaira ${ }^{8}$, Jean-Claude Schmit ${ }^{2}$ and Patrick Goubau*1

\begin{abstract}
Address: ${ }^{1}$ Université Catholique de Louvain, AIDS Reference Laboratory, Avenue Hippocrate 54 -5492, 1200 Bruxelles, Belgium, ${ }^{2}$ CRP Santé, Laboratoire de Rétrovirologie, Val Fleuri 84, 1526 Luxembourg, Luxembourg, ${ }^{3}$ Institute of Tropical Medicine, AIDS Reference Laboratory, Nationalestraat 155, 2000 Antwerpen, Belgium, ${ }^{4}$ Universitair Ziekenhuis Brussel, AIDS Reference Laboratory, Laarbeeklaan 101,1090 Bruxelles, Belgium, ${ }^{5}$ UGent, AIDS Reference Laboratory, DePintelaan 185 Blok A, 9000 Gent, Belgium, 6 University Hospitals Leuven, AIDS Reference Laboratory, Herestraat 49, 3000 Leuven, Belgium, ${ }^{7}$ Hôpital Erasme, AIDS Reference Laboratory, Route de Lennik 808, 1070 Bruxelles, Belgium and ${ }^{8} \mathrm{CHU}$ Liège, AIDS Reference Laboratory, Domaine Universitaire du Sart-Tilman B35, 4000 Liège, Belgium

Email: Jean Ruelle - jean.ruelle@uclouvain.be; François Roman - roman.f@retrovirology.lu; Anne-Thérèse Vandenbroucke - laboratoiresida@uclouvain.be; Christine Lambert - lambert.c@retrovirology.lu; Katrien Fransen - KFransen@itg.be;

Fedoua Echahidi - Fedoua.Echahidi@uzbrussel.be; Denis Piérard - Denis.Pierard@uzbrussel.be; Chris Verhofstede - chris.verhofstede@ugent.be; Kristel Van Laethem - kristel.vanlaethem@uz.kuleuven.ac.be; Marie-Luce Delforge - mdelforg@ulb.ac.be; Dolorès Vaira - dvaira@chu.ulg.ac.be; Jean-Claude Schmit - jc.schmit@crp-sante.lu; Patrick Goubau* - patrick.goubau@uclouvain.be

* Corresponding author
\end{abstract}

Published: 27 February 2008

BMC Infectious Diseases 2008, 8:21 doi:10.1 I86/147|-2334-8-2I

This article is available from: http://www.biomedcentral.com/I47I-2334/8/2I

(C) 2008 Ruelle et al; licensee BioMed Central Ltd.

This is an Open Access article distributed under the terms of the Creative Commons Attribution License (http://creativecommons.org/licenses/by/2.0), which permits unrestricted use, distribution, and reproduction in any medium, provided the original work is properly cited.
Received: 13 September 2007

Accepted: 27 February 2008

\begin{abstract}
Background: Guidelines established for the treatment of HIV-I infection and genotype interpretation do not apply for HIV-2. Data about antiretroviral (ARV) drug efficacy and resistance mutations is scarce.
\end{abstract}

Methods: Clinical data about HIV-2 infected patients in Belgium and Luxembourg were collected and the effect of ARV therapy on plasma viral load and CD4 counts were analysed. Viral RNA encoding for protease (PR) and reverse transcriptase (RT) from ARV-naïve and treated patients were sequenced.

Results: Sixty-five HIV-2 infected patients were included in this cohort. Twenty patients were treated with 25 different ARV combinations in a total of 34 regimens and six months after the start of ARV therapy, only one third achieved viral load suppression. All of these successful regimens bar one contained protease inhibitors (PIs). Mean CD4 gains in the group of viral load suppressors and the group of patients treated with $\mathrm{PI}$-containing regimens were respectively significantly higher than in the group of non-suppressors and the group of $\mathrm{PI}$-sparing regimens. The most frequent mutations selected under therapy (compared to HIV-2 ROD) were V7II, L90M and I89V within PR. Within RT, they were MI84V, QI5IM, VIIII and K65R. All of these mutations, except $K 65 R$ and MI84V, were also found in variable proportions in ARV-naïve patients.

Conclusion: Despite a high rate of ARV treatment failure, better virological and immunological results were achieved with $\mathrm{PI}$ containing regimens. The analysis of polymorphic positions and HIV-2 specific mutations selected during therapy showed for the first time that transmission of drug resistant viruses has occurred in Belgium and Luxembourg. The high heterogeneity in ARV combinations reflects a lack of guidelines for the treatment of HIV-2 infection. 


\section{Background}

Human immunodeficiency virus type 2 (HIV-2) is a lentivirus that causes AIDS [1]. Compared to HIV-1, the disease progression is slower [2] and the transmission rate and plasma viral load are also lower $[3,4]$. Most of the patients infected with HIV-2 are asymptomatic and do not need antiretroviral (ARV) therapy if HIV-1 guidelines are used as a reference [5]. If ARV therapy is started, the choice of drug regimens is limited due to lower drug susceptibilities in comparison to HIV-1. Firstly, HIV-2 is naturally resistant to the non-nucleosidic reverse transcriptase inhibitors (NNRTI) [6,7] and to the fusion inhibitors (FI) that are available on the market [7]. Secondly, reduced susceptibility to some protease inhibitors (PI) has previously been described. HIV-2 displays resistance to amprenavir (APV) [7-9]. Reduced efficacy of nelfinavir (NFV) has been observed in primary isolates from patients [10] and in vivo [11]. In vitro, $\mathrm{IC}_{50}$ to atazanavir (ATV) and tipranavir (TPV) are higher compared to HIV-1, while $\mathrm{IC}_{50}$ to lopinavir (LPV) and darunavir (DRV) are within the same range [12].

The majority of HIV-2 infected persons live in West African countries [13], where HAART is not yet available or has only been implemented recently. No large scale clinical studies have been published on the immunological and virological effects of ARV drugs. Furthermore, there is no consensus for plasma viral load quantification and no commercial assay is available. As a consequence, the interpretation of ARV impact on viral replication raises problems. A first evaluation of viral load measurement techniques [14] as well as the use of an HIV-1 designed kit for HIV-2 RNA quantification has been documented [15]. Some clinical studies based on variable cohort sizes and designs have been made. ARV therapy has shown to have a modest impact on CD4 cell recovery [11,16-18]. Better outcomes were seen with PI-containing regimens in some studies $[16,19,20]$, but others found no difference $[17,21]$.

Although viral evolution occurs slowly in HIV-2 infection [22], the appearance of mutations in the protease (PR) and the reverse transcriptase (RT) genes is common under drug pressure. In HIV-2, these two drug targets harbour amino acid residues which are also involved in HIV-1 drug resistance: $10 \mathrm{~V}, 32 \mathrm{I}, 36 \mathrm{I}, 46 \mathrm{I}, 71 \mathrm{~V}$ in the protease gene [23] and 118I, 215S in the RT gene in addition to the 3 positions linked to the NNRTI resistance (181I, $188 \mathrm{~L}$ and 190A) $[6,24]$. Some mutations appearing under treatment have been clearly linked with therapeutic failure. In the protease, changes were observed that have already been described for HIV-1 drug resistance (10I, 47A, 50V, $54 \mathrm{M}, 71 \mathrm{I}, 82 \mathrm{~F} / \mathrm{L}, 84 \mathrm{~V}, 90 \mathrm{M})$ in addition to HIV-2 specific positions or substitutions (33L, 45R, 56A, 62A, 99F) $[10,25-28]$. The number of mutations needed to confer high-level resistance to PIs is lower in HIV-2 [9]. In the RT, the K65R mutation was selected under tenofovir containing regimens [29] or in combination with Q151M and M184V under stavudine, abacavir or didanosine therapy. The Q151M mutation, which is frequently found [30], has been documented under different NRTI-containing regimens while $\mathrm{M} 184 \mathrm{~V}$ was linked to lamivudine (3TC) use $[16,24,28,31,32]$. Transmission of drug resistant strains may have occurred [33] as well as viruses with a mutational pattern facilitating the acquisition of multi-drug resistance $[9,10]$. In this observational study, a small cohort of HIV-2 infected patients is presented. A positive effect of ARV therapy on clinical parameters was observed, but the impact on CD4 recovery was modest and virological failures were frequent. Drug resistance mutations were detected at failure and some of these mutations were already present in ARV-naïve patients.

\section{Methods \\ Data Collection}

An anonymous data sheet was sent to the clinicians in charge of HIV-2 infected patients using the Belgian AIDS Reference Laboratories network and the Laboratoire de Rétrovirologie in Luxembourg. Patients were identified by a code. Patients with an untypeable HIV status in immunoblot or presumably co-infected with HIV-1 and HIV-2 were excluded. In a first round, epidemiological and clinical data were collected as well as the availability of retrospective samples. In a second round, frozen plasma or serum samples stored in the normal diagnosis and followup settings, were obtained for the sequencing of PR and RT coding regions at different points during the treatment.

\section{Viral load measurements}

Two different methods were used for plasma viral load assessment.

On the one hand, HIV-2 plasma viral load was measured by a real-time PCR in-house assay on a Lightcycler platform [34]. The assay was modified to obtain a sensitivity of 50 RNA copies per millilitre and it used a quantified synthetic RNA as external standard. Viral RNA was extracted from 1 millilitre of plasma or serum by Nuclisens Magnetic Isolation kit on a Mini-Mag apparatus (Biomérieux, Boxtel, The Netherlands). RNA was eluted in $40 \mu \mathrm{l}$ buffer. $8 \mu \mathrm{l}$ were used for reverse transcription using the Transcriptor first strand cDNA synthesis kit (Roche Diagnostics, Penzberg, Germany) with random hexamers (final concentration $60 \mu \mathrm{M}$ ) in a final volume of $20 \mu \mathrm{l}$. The real-time PCR was performed using the Lightcycler FastStart DNA Master PLUS SYBR Green I, $100 \mu$ l kit (Roche Diagnostics, Penzberg, Germany) on a Lightcycler 2.0 platform. Each capillary contained $48 \mu \mathrm{l}$ PCR grade water, $6 \mu \mathrm{l}$ of each primer (in a final concentration of $0.6 \mu \mathrm{M}-$ see ref 30 for sequences), $20 \mu$ of Master Mix provided in 
the kit and $20 \mu \mathrm{l}$ cDNA. Each run consisted of forty cycles of amplification $\left(95^{\circ} \mathrm{C} 15 \mathrm{~s}-60^{\circ} \mathrm{C} 40 \mathrm{~s}-72^{\circ} \mathrm{C} 30 \mathrm{~s}\right)$ followed by a melting curve analysis.

On the other hand, a semi-quantitative assay was used as described by Van Kerckhoven et al. [35] with HIV-2 specific primers described in [36]. The latter method was the reference in Belgium before 2004 and is still used for the follow-up of some patients.

\section{Genotype}

RT-PCR and inner PCR were performed as described by Colson et al. [27] and PCR products were analysed in a 2\% agarose gel with ethidium bromide. This protocol generated a 1507 bp fragment which covers the protease and the RT coding regions. Viruses of subtype B failed to be amplified. In this case, two separate inner PCR reactions were performed using $2 \mu \mathrm{l}$ of RT-PCR product. One reaction amplified the RT coding region with the forward primer JR23 5'-TAATGACAGGCGACACC-3' and the reverse primer JR24 5'-TGTGCTGCCCAATTTAG-3', both at a final concentration of $0.2 \mu \mathrm{M}$. PCR conditions were as follows: $10 \mathrm{~min}$ at $94^{\circ} \mathrm{C}$, followed by 40 cycles of $30 \mathrm{~s}$ at $94^{\circ} \mathrm{C}, 45 \mathrm{~s}$ at $57^{\circ} \mathrm{C}, 1.5 \mathrm{~min}$ at $72^{\circ} \mathrm{C}$, and finally an incubation of $10 \mathrm{~min}$ at $72^{\circ} \mathrm{C}$. The second reaction amplified the protease coding region, with the forward primer JR2 1 5'-AGACACCATACAGGGAGC-3' and the reverse primer JR41 5'-TGTATGGATTAGTAGGAGGCG-3' under the same experimental conditions.

PCR products were then purified using the QIAquick PCR purification kit (QIAGEN, Hilden, Germany). Twenty nanograms of each PCR product were sequenced with the BigDye Terminator v1.1 cycle sequencing kit (Applied Biosystems, Foster City, CA, USA). Primers used for sequencing of PCR products obtained by the first protocol were H2Mp3 [27] and JR 40 5'-AGGATTAGTTGGAGGTGC-3' for the protease coding region, and JR23, JR24, JR25 5'-GCACCTCCAACTAATCCT-3' and JR 26 5'-GCAGTATATGGTCTAAAGTC-3' for the RT coding region. If the first PCR protocol was not successful, the protease coding region was sequenced with primers JR21 and JR41, while the RT coding region was sequenced with JR23, JR34 5'AGTTGAGCTGCCCAATTTAA-3' and JR35 5'-CGCCTCCTACTAATCCATACA-3'. Products of the sequencing reaction were purified by ethanol-acetate precipitation and analysed on an ABI Prism 310 genetic analyser (Applied Biosystems).

\section{Statistical analysis}

Statistical analysis was performed using the JMP software version 6 (SAS institute, Cary, NC, USA). The significant effect of ARV therapy on plasma viral load was assessed using a Kaplan-Meyer survival curve in order to consider if virological failure was the outcome at three different time reference points after therapy initiation. To interpret the impact of ARV therapy on CD4 count evolution, data was first standardised to obtain CD4 values at the same reference points for every therapy, using a linear regression model to interpolate values between existing measurements. In a first model, delta CD4 values were calculated from treatment initiation at intervals of three months. Two different parameters were tested: the therapy (PI-containing or not) and virological failure. Analysis of the variance between groups was done using a Tukey test. In a second model, the raw CD4 data on a time scale between the two different therapy groups was considered and response specification was assessed by constructing linear combinations with a Manova fit model.

\section{GenBank accession numbers}

Earliest samples from 30 patients were submitted to GenBank and received accession numbers from EF611309 to EF611338: the first 23 were ARV-naïve (from EF611309 to EF611331) and the last 7 were treated patients.

\section{Ethical approval}

This evaluation was approved by the ethical committee of the Medical Faculty of the Université Catholique de Louvain.

\section{Results \\ Epidemiological data}

Sixty-five patients were included in our cohort and data is summarised in Table 1 . The male/female ratio was about 1 , median age was 42 at the end of 2006, and the transmission route was essentially heterosexual. The majority (i.e. 63\%) of cases were of West African origin, although cases from Europe, central Africa and Asia were recorded. Twenty out of the 65 patients received ARV therapy and 15 were still on therapy at the end of 2006.

\section{Effect of ARV therapy on plasma viral load}

As different methods were used for the viral load determination, and in the absence of a gold standard, we chose qualitative criteria to evaluate the efficacy of therapy. Either the regimen successfully suppressed viral replication and plasma viral load became undetectable, or replication was not suppressed and this was defined as virological failure. The threshold used was the detection limit of the least sensitive method. All therapies were started in the presence of a detectable viral load and baseline viral load values are given in Table 2 . The presence or absence of viral replication was investigated at three points: 6,12 and 24 months after initiation of therapy. Overall, $60 \%, 53 \%$ and $50 \%$ of virological failures were observed respectively. Details are available in Table 2. Twenty out of 34 regimens were first line therapies, and 7 second-line therapies were initiated in the presence of resistance mutations. A Kaplan-Meier survival curve was 
Table I: Epidemiological data about the 65 patients from Belgium and Luxembourg.

\begin{tabular}{|c|c|c|}
\hline \multirow[t]{3}{*}{ Gender } & Female & $31(48.5 \%)$ \\
\hline & Male & $33(51.5 \%)$ \\
\hline & Unknown & 1 \\
\hline \multirow[t]{2}{*}{ Age } & Mean & 42.84 years (range from 25 to $7 \mathrm{I})$ \\
\hline & Median & 42 years \\
\hline \multirow[t]{18}{*}{ Countries of origin } & West Africa & $29(63 \%)$ \\
\hline & Ghana & 8 \\
\hline & Ivory Coast & 7 \\
\hline & Cape Verde Islands & 5 \\
\hline & Guinea-Bissau & 3 \\
\hline & Guinea & 2 \\
\hline & Senegal & 1 \\
\hline & Liberia & 1 \\
\hline & Nigeria & 1 \\
\hline & Burkina-Faso & I \\
\hline & Europe & II (24\%) \\
\hline & Belgium & 6 \\
\hline & Portugal & 5 \\
\hline & Central and Southern Africa & $4(8.5 \%)$ \\
\hline & Democratic Republic Congo & 3 \\
\hline & South-Africa & 1 \\
\hline & Asia: Nepal & $2(4 \%)$ \\
\hline & Not documented & 19 \\
\hline \multirow[t]{5}{*}{ Transmission } & Heterosexual & 37 (86\%) \\
\hline & Homosexual (MSM) & $2(4.5 \%)$ \\
\hline & Intra-venous drug use & $2(4.5 \%)$ \\
\hline & Transfusion & $2(4.5 \%)$ \\
\hline & Not documented & 22 \\
\hline \multirow[t]{4}{*}{ Year of infection } & Between 2002 and 2006 & $10(33 \%)$ \\
\hline & Between 1997 and 200I & $7(23 \%)$ \\
\hline & Before 1997 & $13(43 \%)$ \\
\hline & Not documented & 22 \\
\hline \multirow[t]{5}{*}{ ARV use } & Treated & $20(31 \%)$ \\
\hline & Exposed to NRTIs only & 5 \\
\hline & Exposed to NRTls and Pls & 15 \\
\hline & Treated at the end of 2006 & 15 \\
\hline & Never been treated & $45(69 \%)$ \\
\hline \multirow[t]{3}{*}{ Subtype } & A & $25(83 \%)$ \\
\hline & B & $5(17 \%)$ \\
\hline & Not documented & 35 \\
\hline
\end{tabular}

The percentages were calculated for patients with available data (collected until 2006-I2-3I). ARV: antiretroviral therapy

drawn to compare the appearance of virological failure in PI-containing and PI-sparing regimens (not shown). A significant difference existed between the two $(\mathrm{p}=0.02)$ : the mean times to virological failure were 9.42 months for the PI-containing group and 1.2 months for the PI-sparing group.

\section{Effect of ARV therapy on CD4 count}

Information on CD4 counts evolution was gathered for 25 therapies. Three suboptimal therapies were excluded from the statistical analysis (Table 2, lines 23-25). Mean
CD4 at baseline was 263 cells $/ \mathrm{mm}^{3}$ (ranging from 10 to 737). In the group of patients who had never been treated, data from 10 patients with baseline CD4 counts between the same ranges were considered, with a mean at the first visit of 402 cells $/ \mathrm{mm}^{3}(193-660)$. Over one year, the mean loss was $16 \mathrm{CD} 4 / \mathrm{mm}^{3}$.

The CD4 gain after therapy initiation was plotted on a time scale. The PI-containing and PI-sparing groups, as well as the viral load suppressor and non-suppressor groups, were compared (Table 3 ). A Tukey test was per- 
Table 2: Effect of ARV therapy on plasma viral load levels after 6, 12 and 24 months.

Baseline VL

VL 6 m VL 12 m VL 24 m Baseline CD4 Delta CD4 12 m

\section{Pl-containing regimens}

\begin{tabular}{|c|c|c|c|c|c|c|c|}
\hline I & AZT-3TC-LPV/r & 3.65 & $U$ & $U$ & $\cup$ & 40 & +323 \\
\hline 2 & d4T-3TC-IDV/r & 2.36 & $\cup$ & $\cup$ & $\cup$ & 490 & +231 \\
\hline 3 & d4T-ABC-LPV/r & 5.36 & D & D & $\mathbf{D}$ & 338 & +180 \\
\hline 4 & 3TC-TDF-SQV-ATV/r & 5.73 & $\cup$ & $\cup$ & NA & 92 & $+|6|$ \\
\hline 5 & d4T-3TC-NFV & 3.36 & $\cup$ & U & $\cup$ & 261 & +147 \\
\hline 6 & TDF-FTC-ATV/r & 5.40 & $\mathrm{D}$ & NA & NA & 10 & +140 \\
\hline 7 & AZT-3TC-LPV/r & 4.05 & U & $\cup$ & $U$ & 62 & +136 \\
\hline 8 & d4T-3TC-IDV & NA & NA & NA & NA & 527 & +89 \\
\hline 9 & d4T-3TC-LPV/r & 4.36 & $\cup$ & $U$ & $U$ & 128 & +67 \\
\hline 10 & ddl-TDF-IDV/r & 3.60 & $\mathrm{D}$ & $\cup$ & NA & 120 & +50 \\
\hline II & d4T-3TC-NFV & 4.36 & D & D & D & 380 & +49 \\
\hline 12 & AZT-3TC-FPV/r & 3.49 & D & $\mathrm{D}$ & NA & 290 & +40 \\
\hline 13 & AZT-3TC-IDV & 5.29 & $\cup$ & $\cup$ & $\mathrm{D}$ & 280 & +21 \\
\hline 14 & d4T-3TC-NFV & 4.36 & $\mathrm{D}$ & $\mathbf{D}$ & NA & 257 & -14 \\
\hline 15 & 3TC-TDF-IDV/r & 2.40 & $\mathbf{D}$ & $\mathbf{D}$ & NA & 180 & -31 \\
\hline & Mean & 4.13 & & & & 230 & +106 \\
\hline & Median & 4.21 & & & & 257 & +89 \\
\hline
\end{tabular}

\section{Pl-sparing regimens}

\begin{tabular}{|c|c|c|c|c|c|c|c|}
\hline 16 & AZT-3TC-ABC & 3.01 & D & D & D & 150 & +57 \\
\hline 17 & d4T-3TC-ABC-TDF & 3.36 & $U$ & U & $U$ & 630 & +12 \\
\hline 18 & ddl-TDF-ABC & 4.05 & D & D & D & 174 & -8 \\
\hline 19 & AZT-3TC-ABC & 5.07 & D & D & NA & 166 & -53 \\
\hline 20 & AZT-3TC-ABC & 2.40 & $\mathrm{D}$ & NA & NA & 737 & -60 \\
\hline 21 & 3TC-ABC-TDF & 3.36 & NA & $\mathrm{D}$ & NA & 195 & -61 \\
\hline \multirow[t]{3}{*}{22} & AZT-3TC-ABC & 4,78 & D & D & D & 280 & -62 \\
\hline & Mean & 3.72 & & & & 333 & -25 \\
\hline & Median & 3.36 & & & & 195 & .53 \\
\hline
\end{tabular}

\section{Regimens not included in the comparison above}

\begin{tabular}{ll}
\hline 23 & AZT-3TC-NVP \\
24 & AZT \\
25 & ddl-d4T-EFV \\
& \\
26 & AZT-3TC-NFV \\
27 & 3TC-ABC-FPV/r \\
28 & AZT-3TC-SQV/r \\
29 & AZT-3TC-LPV/r \\
30 & AZT \\
31 & AZT \\
32 & AZT-3TC-LPV/r \\
33 & $3 T C-d 4 T$ \\
34 & ddl-d4T-ABC-SQV-NFV
\end{tabular}

$$
\begin{gathered}
\text { NNRTI is not active, suboptimal } \\
\text { bitherapy } \\
\text { Suboptimal monotherapy } \\
\text { NNRTI is not active, suboptimal } \\
\text { bitherapy } \\
\text { Therapy switched after I month } \\
\text { Therapy switched after I month } \\
\text { Therapy started end of } 2006 \\
\text { Therapy started end of } 2006 \\
\text { Pregnancy, prevention MTCT } \\
\text { Pregnancy, prevention MTCT } \\
\text { Pregnancy, prevention MTCT } \\
\text { Lost to follow-up } \\
\text { Lost to follow-up }
\end{gathered}
$$

Regimens were classified within the PI-containing and PI-sparing groups from the highest to the lowest delta CD4 counts after 12 months of therapy.

Baseline viral load levels are expressed in log copies/ml of plasma, CD4 counts are expressed in cells $/ \mathrm{mm}^{3}$.

All regimens are first line therapies, except regimens 3, 4, 7 and I8 to 22 which are second line therapies; 6, 10, I7, 2I are third line therapies and 15 is a fourth line therapy.

$\mathrm{U}=$ undetectable plasma viral load; $\mathrm{D}=$ detectable viral load; NA = not available (unavailable sample or end of the treatment); $\mathrm{MTCT}=$ mother to child transmission. 
Table 3: Effect of ARV therapy on CD4 counts after I 2 months.

\begin{tabular}{|c|c|c|c|c|c|c|c|c|c|}
\hline & \multicolumn{4}{|c|}{ BASELINE CD4 (cells/mm³) } & \multicolumn{4}{|c|}{ DELTA CD4 after 12 months } & \\
\hline & Mean & Median & Interval & & Mean & Median & Interval & & \\
\hline Non-treated $(\mathrm{N}=10)$ & 402 & 427 & 193 & 660 & -16 & -21 & -112 & 64 & \\
\hline ARV therapies $(n=22)$ & 263 & 226 & 10 & 737 & 64 & 50 & -62 & 323 & \\
\hline - with Pls $(n=15)$ & 230 & 237 & 10 & 527 & 106 & 89 & -31 & 323 & $p=0,0003$ \\
\hline - without Pls $(n=7)$ & 333 & 195 & 150 & 737 & -25 & -53 & -62 & 57 & \\
\hline - undetectable VL $(n=8)$ & 248 & 195 & 40 & 630 & 137 & $14 \mid$ & 12 & 323 & $P<0,0001$ \\
\hline - detectable VL $(n=14)$ & 272 & 226 & 10 & 737 & 23 & 16 & -62 & 180 & \\
\hline
\end{tabular}

Interval columns give minimum and maximum CD4 cells $/ \mathrm{mm}^{3} . \mathrm{N}$ is the number of patients for the untreated group, and $\mathrm{n}$ is the number of therapies in the treated group. $\mathrm{P}$ values were obtained by the analysis of variances using a Tukey test (see Methods section). $\mathrm{PI}=\mathrm{protease}$ inhibitor, $\mathrm{VL}=$ plasma viral load.

formed, comparing the variance in CD4 gain at intervals of 3 months after therapy initiation. Viral load suppressors had a distinctively higher CD4 gain than viral load non-suppressors $(\mathrm{p}<0.0001)$, with respective mean gains of 137 and $23 \mathrm{CD} 4 / \mathrm{mm}^{3}$ after 12 months. Differences in treatment had a significant influence on CD4 gain $(\mathrm{p}=$ 0.003 ). A mean gain of $106 \mathrm{CD} 4 / \mathrm{mm}^{3} /$ year was observed in the PI-group while a mean loss of $25 \mathrm{CD} 4 / \mathrm{mm}^{3} /$ year was obtained in the PI-sparing group. A second test was performed to establish the immunological response based on raw CD4 data using a Manova test. After 12 months of treatment, a gain of $96 \mathrm{CD} 4 / \mathrm{mm}^{3}$ in the PI-group and a loss of $11 \mathrm{CD} 4 / \mathrm{mm}^{3}$ in the PI-sparing group had been recorded. For the PI-group, this gain was already observed after 3 months of therapy and was maintained afterwards while the decrease observed for the PI-sparing group did not significant differ from zero.

Finally, baseline CD4 counts were stratified in three groups, more than 400, between 400 and 200 and less than 200 cells $/ \mathrm{mm}^{3}$. The same tendencies were observed for respectively 4, 7 and 11 different treatments but they had poor statistical relevance, especially for the groups higher than $200 \mathrm{CD} 4 / \mathrm{mm}^{3}$.

\section{Mutations selected on therapy, polymorphisms and resistance at baseline}

Table 4 shows the mutations that appeared in the PR and RT during ARV therapy. The ROD strain (subtype A) was used as reference for the description of mutations.

In the PR, the most frequent mutation was V71I: it showed 3 times under NFV therapy. This mutation was associated once with V62A and L99F, once with T56A and V62M and in both cases with a plasma viral load higher than 3 log copies per $\mathrm{ml}$. In the third case V71I was detected as part of a combination with V71T before viral load suppression. The I89V and L90M mutations were each detected twice, the latter under an ATV/r containing

Table 4: Mutations selected on ARV therapy.

\begin{tabular}{|c|c|c|c|c|}
\hline Patient & ARV drug regimens & Mutations selected in the PR & Mutations selected in the $\mathbf{R T}$ & Corresponding line in table 2 \\
\hline \multirow[t]{2}{*}{ A } & d4T-3TC-NFV & V62A, V7II, L99F & MI84V & 14 \\
\hline & d4T-ABC-LPV/r & $+\mathrm{S} 43 \mathrm{I}, \mathrm{K} 45 \mathrm{R}, \mathrm{V} 47 \mathrm{~A}, 189 \mathrm{~V}$ & + IIOV, K35T, K82R, YII5F, QI5IM & 3 \\
\hline \multirow[t]{2}{*}{ B } & AZT-3TC-ABC & & MI84V & 20 \\
\hline & d4T-3TC-ABC-TDF & & $+A 62 V, K 65 R, V I I I I$ & 17 \\
\hline \multirow[t]{3}{*}{$\mathrm{C}$} & AZT-3TC-NVP & & QI5IM, MI84V & 23 \\
\hline & ddl-TDF-ABC & & + K65R, N69T, VIIII, D218E & 18 \\
\hline & 3TC-ABC-TDF & & $+190 \mathrm{~V}, \mathrm{~S} 215 \mathrm{~T}$ & 21 \\
\hline $\mathrm{D}$ & d4T-3TC-NFV & T56A, V62M, V7II & MI84V & 11 \\
\hline$E$ & d4T-3TC-NFV & V7II/T $(*)$ & & 5 \\
\hline $\mathrm{F}$ & 3TC-ABC-FPV/r & I54M, I89V, L90M & MI84V & 27 \\
\hline G & AZT-3TC-ABC & & $\begin{array}{l}\text { K65R, N69S, V83I, 190V, VIIIII, MI84I/ } \\
\text { V, F2I4L, Q I5IM, YIIIFF }\end{array}$ & 16 \\
\hline \multirow[t]{2}{*}{$\mathrm{H}$} & AZT-3TC-ABC & & $\mathrm{M} 184 \mathrm{~V}$ & 22 \\
\hline & TDF-FTC-ATV/r & L90M & & 6 \\
\hline I & AZT-3TC-ABC & & $\begin{array}{c}\text { MI84V, K70N, K35R, K64R, K82R, } \\
\text { QI5IM }\end{array}$ & 19 \\
\hline
\end{tabular}


regimen and in a FPV/r containing regimen in association with I54M and I89V mutations.

In the RT, the most frequent mutation selected on therapy was $\mathrm{M} 184 \mathrm{~V}$. It appeared in eight different treatment failures with different regimens all containing 3TC, which was also the most prescribed ARV drug.

The Q151M mutation was found in viruses from 4 patients with different regimens. Firstly, in association with I10V, K35T, K82R, Y115F and M184V in patient A who had a history of AZT, 3TC, d4T and ABC exposure. Secondly, Q151M appeared in association with the M184V mutation under AZT/3TC pressure (patient C). Thirdly, in patient G, Q151M was observed in association with $\mathrm{M} 184 \mathrm{~V}$ and $\mathrm{F} 214 \mathrm{~L}$ under AZT/3TC/ABC pressure. The further continuation of this regimen subsequently resulted in the appearance of K65R, N69S, V83I, I90V and V111I. Lastly, and again under AZT/3TC/ABC pressure (patient I), the Q151M appeared on a M184V background after the disappearance of $\mathrm{K} 70 \mathrm{~N}$ and with the concomitant presence of K35R, K64R and K82R.

The K65R mutation was selected 3 times on therapy and the only drug in common for the 3 regimens was $\mathrm{ABC}$.

Fig. 1 and 2 show the variations found in the PR and the RT, respectively from 20 and 23 ARV-naïve patients. In the $\mathrm{PR}$, the most polymorphic positions were 14, 40, 65, 68 and 70. The mutations V62A, V71I, I89V and L99F, all linked to virological failure, were found in viruses from naïve patients.

In the RT, the most polymorphic positions were $5,10,11$, $28,64,82,111,121,123,126,162,167,176,180,200$, 227, 228 and 251, with 7 or more variants out of 23 sequences from different naïve patients. Note that the Q151M mutation was also found in a virus from a recently diagnosed naïve patient originating from Belgium. Phylogenetic analysis of the RT sequences (not shown) showed that this virus was related to another one

\section{PROTEASE}

\begin{tabular}{|c|c|c|c|c|c|}
\hline 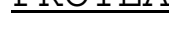 & 10 & 20 & 3 & 0 & 50 \\
\hline $\operatorname{ROD}(\mathrm{A})$ & PQFSLWKRPV & VTAYIEGQPV & EVLLDTGADD & SIVAGIELGN & NYSPKIVGGI \\
\hline $\mathrm{EHO}(\mathrm{B})$ & PQFSLWRRPV & VKATIEGQSV & EVLLDTGADD & SIVAGIELGS & NYTPKIVGGI \\
\hline \multirow{5}{*}{ 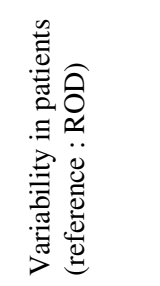 } & $\mathrm{P} 1 \mathrm{~L}(1)$ & \multicolumn{2}{|l|}{$\mathrm{T} 12 \mathrm{~K}(2), \mathrm{I}(2), \mathrm{M}(2)$} & $\mathrm{I} 36 \mathrm{~V}(1)$ & $\mathrm{N} 41 \mathrm{D}(2)$ \\
\hline & $\mathrm{F} 3 \mathrm{~L}(1)$ & $\mathrm{Y} 14 \mathrm{H}(11), \mathrm{N}(2)$ & & $\mathrm{E} 37 \mathrm{D}(1)$ & S43T(6), N(2), R(1) \\
\hline & S4P(3) & $\mathrm{I} 15 \mathrm{~V}(1)$ & & N40S(13), D(4) & $\mathrm{K} 45 \mathrm{Q}(1)$ \\
\hline & $\mathrm{K} 7 \mathrm{R}(3), \mathrm{E}(2)$ & $\mathrm{G} 17 \mathrm{D}(3), \mathrm{R}(1), \mathrm{E}(1)$ & & & $\mathrm{I} 46 \mathrm{~V}(2)$ \\
\hline & V10I(1) & $\mathrm{P} 19 \mathrm{~S}(1)$ & & & \\
\hline \multicolumn{2}{|r|}{60} & 70 & 80 & 90 & 100 \\
\hline $\mathrm{ROD}(\mathrm{A})$ & GGFINTKEYK & NVEIEVLNKK & VRATIMTGDT & PINIFGRNIL & TALGMSLNLP \\
\hline $\mathrm{EHO}(\mathrm{B})$ & GGFINTNEYK & NVEIEVVGKR & VRATVMTGDT & PINIFGRNIL & NSLGMTLNFP \\
\hline \multirow{6}{*}{ 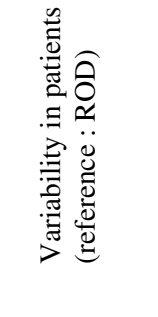 } & $\mathrm{T} 56 \mathrm{~V}(1)$ & N61D(3) & V71I(3) & F85L(1) & T91A(1), N(1), S(1) \\
\hline & K60R(1) & V62A(1), I(1) & $\mathrm{R} 72 \mathrm{~K}(2), \mathrm{Q}(1)$ & $\mathrm{I} 89 \mathrm{~V}(2)$ & L93I(1) \\
\hline & & $\mathrm{E} 65 \mathrm{~K}(11), \mathrm{R}(1)$ & $\mathrm{T} 74 \mathrm{~A}(1)$ & & S96T(2) \\
\hline & & L67V(1) & $\mathrm{D} 79 \mathrm{E}(1)$ & & L99F(3) \\
\hline & & N68G(7) & & & \\
\hline & & K70R(14), T(1) & & & \\
\hline
\end{tabular}

\section{Figure I}

Variations found in the HIV-2 protease. Polymorphisms of the PR sequenced from 20 antiretroviral-naïve patients are compared to ROD and EHO strains (respectively subtypes $A$ and $B$ ). $\mathbf{X}$ (bold): amino acid residue where variability was found in ARV-naïve patients. $(\mathrm{N})$ : number of samples from naïve patients harbouring the mutation. Red: mutations that were selected under ARV therapy in this study (Table 4). 


\section{REVERSE TRANSCRIPTASE}

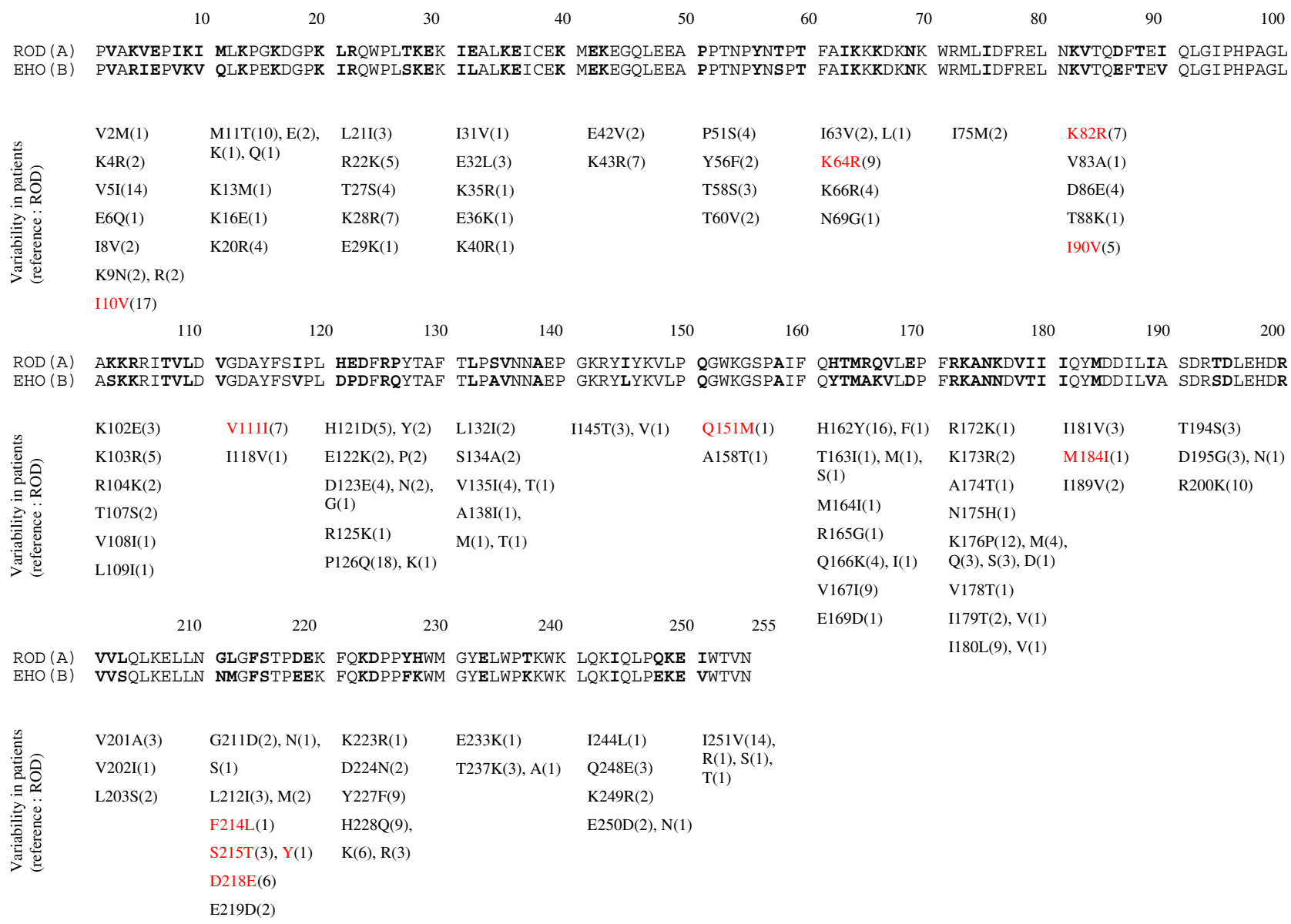

\section{Figure 2}

Variations found in the HIV-2 reverse transcriptase. Polymorphisms of RT from 23 antiretroviral-naive patients are compared to ROD and EHO strains (respectively subtypes $A$ and $B$ ). $\mathbf{X}$ (bold): amino acid residue where variability was found in $A R V$-naïve patients. $(\mathrm{N})$ : number of samples from naive patients harbouring the mutation. Red: mutations that were selected under ARV therapy in this study (Table 4).

also harbouring the Q151M mutation. The patients affected were the only 2 homosexual men of this group. Furthermore, positions 10, 35, 64, 69, 82, 83, 90 and 111 were found in variable proportions in naïve patients (see Fig 2 for details). The M184I mutation was found in one ARV-naïve patient but was present in the provirus only.

\section{Discussion}

We describe retrospective data on 65 HIV-2 infected patients, with insights on the effect of ARV therapy on plasma viral load, CD4 counts and the selection of drug related mutations.

In regard to the epidemiological picture of this cohort, the main characteristics do fit with the trends described in literature: the majority of patients originate from West
Africa, the transmission is essentially heterosexual, and the male/female ratio is about $1[3,37]$. We also recorded patients originating from countries where the presence of HIV-2 had not yet been reported, such as R.D. Congo, South-Africa and Nepal. Although Central and Southern Africa is confronted with a huge HIV-1 epidemic, HIV-2 is not completely absent [38].

The impact of ARV therapy on viral replication was studied using a qualitative marker: the presence or absence of a detectable plasma viral load. Up until now several assays had been described for HIV-2 quantification [15,34,3942], the majority of them using real-time PCR. But even among these techniques, the standards used differ, resulting in important discrepancies in absolute quantification [14]. 
We observed that viral load suppression was achieved with PI-containing regimens in $50 \%$ of the therapies after six months of treatment. Only one therapy with 4 NRTI resulted in an undetectable viral load within the same period. This study faced three main drawbacks. Firstly, the number of patients recorded was limited and many different ARV combinations were given. We do know that some drugs have a reduced activity against HIV-2 and their impact in the PI- containing or sparing regimens could have influenced the results. Secondly, we had no data on adherence but there were no indications for a different adherence in the PI and non-PI subgroups. Thirdly, long term efficacy of ARV drugs on viral load suppression was difficult to evaluate as a failing regimen was stopped as soon as the plasma viral load results became available to the clinician. Nevertheless, long term viral suppression was observed only within PI-containing regimens. The viral load levels at baseline could not explain this difference as they were higher in the PI-treated group. This observation is consistent both with the knowledge we have of HAART in HIV-1, where guidelines recommend the administration of 2 different classes of drug [5], and with the CD4 count evolution in our group of patients.

The CD4 gain was significantly greater if PIs were included in the therapy compared to regimens with RTIs only. We observed a mean loss of $16 \mathrm{CD} 4 / \mathrm{mm}^{3}$ per year in a group of 10 non-treated patients. This loss is similar to what was found elsewhere for HIV-2 [43]. The CD4 loss in untreated patients did not differ significantly from the loss observed in the subgroup of virological failures or from the subgroup treated without PIs. Our study further indicates that the best results in terms of immunological reconstitution were obtained when the plasma viral load was fully suppressed. Other studies have found a CD4 gain in HIV-2 treated patients between 41 [17] and 163 [11] cells per year. If we consider all the patients treated with 3 or more ARV studied here, the CD4 gain of 64 $\mathrm{CD} 4 / \mathrm{mm}^{3}$ per year seems modest. Several hypotheses may explain this moderate efficacy. First, PR and RT catalytic sites differ between HIV-1 and HIV-2 despite a common structural backbone at protein level and therefore, the sensitivity of HIV-2 to drugs differs from HIV-1 $[6,7,44]$. Some of the regimens observed include NFV and APV, to which sensitivity is reduced $[7,8,11]$.

Moreover, we know that the plasma viral load is lower in HIV-2 infection compared to HIV-1 in spite of an equivalent proviral load [45]. The viral replication cycle may differ from HIV-1, with a lower number of infective cycles. Drugs now available target the replicative cycle and may be therefore less active. Finally, there are no criteria or guidelines to start therapy based on biological parameters and more clinical studies are needed to determine the optimal conditions for a successful HIV-2 therapy.
The use of suboptimal regimens will prompt the appearance of resistant viruses. Here, we observed mutations in the reverse transcriptase that had already been described before: K65R, Q151M and M184V [28-32]. These were the mutations most frequently observed under therapy. We also noted the frequent occurrence of the V111I mutation: this mutation was present in 7 out of 23 ARV-naïve patients, but also showed 3 times in association with K65R under various NRTI-only regimens. A major challenge with genotype interpretation is the discrimination between natural polymorphisms and changes affecting sensitivity to ARV drugs. Changes that appeared under therapy at RT positions 10, 64, 82, 90, 111, 167 and 218 (see Fig. 2) were widely found in ARV-naïve patients [46]. Phenotypic studies are needed to assess their impact on resistance. For instance, the K35R mutation, already described elsewhere [24], was selected under AZT/ABC/ 3TC therapy but was also present in a naïve patient. The $\mathrm{K} 70 \mathrm{~N}$, also selected on AZT/ABC/3TC therapy was observed in vitro when ROD and EHO HIV-2 strains were cultured under $\mathrm{ABC}$ pressure [47]. We observed no selection of $\mathrm{Y}$ at position 215 [48]. S215T was selected in 3TC/ ABC/TDF therapy, but 215T and 215Y were also observed in naïve patients.

In the PR, the appearance of mutations was associated with the 3 regimens that included NFV. The V71I mutation was common to the 3 cases. This same mutation was also retrieved in 3 others naïve patients. The V47A mutation was observed elsewhere under LPV/r treatment [49]. We confirmed the presence of this mutation by LPV/r in one case of second line virological failure.

It is known that the L90M mutation occurs in vitro under SQV [25,47] and NFV pressure [9], and in vivo during $\mathrm{NFV}, \mathrm{IDV}, \mathrm{SQV} / \mathrm{r}$ and LPV/r treatments $[26,49]$. We found presence of L9OM under FPV/r and ATV/r containing regimens, suggesting that L90M is a multi-resistance mutation.

Although more phenotypic and clinical studies are needed to assess the impact of mutations in more detail, our observations suggest a low genetic barrier to resistance. The use of a PI-based regimen, which our results tend to recommend, could be limited by the selection of multi-resistant strains.

Besides substitutions that are not clearly linked to resistance such as K35R, I90V and V111I in the RT, we observed viruses or proviruses from naïve patients harbouring known resistance mutations like Q151M and M184I. In the protease, we found mutations at positions $62,71,89$ and 99 in viruses from ARV naïve patients, positions which are possibly linked to resistance $[9,27]$. This indi- 
cates for the first time that transmission of resistant strains does occur in Belgium and Luxembourg.

\section{Conclusion}

This observational study showed that treatment of HIV-2 infection is heterogeneous in Belgium and Luxembourg and has moderate efficacy. Immune recovery was observed with PI-containing drug combinations when plasma viral load was suppressed. Selection of resistance mutations occurred in both PR and RT. Analysis of polymorphisms in ARV naïve patients and mutations appearing during therapy showed for the first time that transmission of resistant HIV-2 strains has occurred in Belgium and Luxembourg. This implies a reduced usefulness of ARV for the treatment of HIV-2 infections in the future. There is therefore an urgent need for genotype interpretation rules as well as standardisation and implementation of HIV-2 laboratory techniques.

\section{Competing interests}

The author(s) declare that they have no competing interests.

\section{Authors' contributions}

JR coordinated the data and samples collections from the different Belgian centres, analysed the clinical data and the genotypes, and drafted the manuscript. FR coordinated the study in Luxembourg. ATV and CL performed the molecular biology assays and aligned the sequences. $\mathrm{KF}, \mathrm{FE}, \mathrm{DP}, \mathrm{CF}, \mathrm{KVL}, \mathrm{MLD}$ and DV all contributed to the data and samples collections in their own HIV centre. JCS and PG participated in the design of the study and helped to draft the manuscript. All authors read and approved the final manuscript.

\section{Acknowledgements}

This work was in part supported by the «Prix Pierre et Colette Bauchau», 2004, Université Catholique de Louvain, Belgium.

\section{References}

I. Clavel F, Mansinho K, Chamaret S, Guetard D, Favier V, Nina J, Santos-Ferreira MO, Champalimaud JL, Montagnier L: Human immunodeficiency virus type 2 infection associated with AIDS in West Africa. N Engl ] Med 1987, 3 I 6: I | 80- I I85.

2. Marlink R, Kanki P, Thior I, Travers K, Eisen G, Siby T, Traore I, Hsieh CC, Dia MC, Gueye EH, Hellinger J, Guèye-Ndiaye A, Sankalé JL, Ndoye I, Mboup S, Essex M: Reduced rate of disease development after HIV-2 infection as compared to HIV-I. Science 1994, 265: I587-I590.

3. De Cock KM, Adjorlolo G, Ekpini E, Sibailly T, Kouadio J, Maran M, Brattegaard K, Vetter KM, Doorly R, Gayle HD: Epidemiology and transmission of HIV-2. Why there is no HIV-2 pandemic. JAMA 1993, 270:2083-2086

4. Simon F, Matheron S, Tamalet C, Loussert-Ajaka I, Bartczak S, Pépin JM, Dhiver C, Gamba E, Elbim C, Gastaut JA, Saimot A, Brun-Vézinet $\mathrm{F}$ : Cellular and plasma viral load in patients infected with HIV-2. AIDS 1993, 7:1411-1417.

5. Guidelines for the use of antiretroviral agents in HIV-I infected adults and adolescents. DHHS [http://aidsinfo.nih.gov/ guidelines]. Revised May 4, 2006.

6. Ren J, Bird LE, Chamberlain PP, Stewart-Jones GB, Stuart DI, Stammers DK: Structure of HIV-2 reverse transcriptase at 2.35-A resolution and the mechanism of resistance to non-nucleoside inhibitors. Proc Natl Acad Sci USA 2002, 99: | 44 I0-|44I 5.

7. Witvrouw M, Pannecouque C, Switzer WM, Folks TM, De Clercq E, Heneine W: Susceptibility of HIV-2, SIV and SHIV to various anti-HIV-I compounds: implications for treatment and postexposure prophylaxis. Antivir Ther 2004, 9:57-65.

8. Descamps D: In vitro phenotypic susceptibility of HIV-2 clinical isolates to protease inhibitors: amprenavir, atazanavir, lopinavir and tipranavir [abstract 93]. XV International HIV drug resistance workshop : basic principles and clinical implications: 13-17 June 2006; Sitges, Spain .

9. Ntemgwa M, Brenner BG, Oliveira M, Moisi D, Wainberg MA: Natural polymorphisms in the human immunodeficiency virus type 2 protease can accelerate time to development of resistance to protease inhibitors. Antimicrob Agents Chemother 2007, 5 I :604-6I0.

10. Rodés B, Sheldon J, Toro C, Jiménez V, Alvarez A, Soriano V: Susceptibility to protease inhibitors in HIV-2 primary isolates from patients failing antiretroviral therapy. J Antimicrob Chemother 2006, 57:709-713.

II. Adjé-Touré CA, Cheingsong R, Garcia-Lerma JG, Eholié S, Borget MY, Bouchez JM, Otten RA, Maurice C, Sassan-Morokro M, Ekpini RE, Nolan M, Chorba T, Heneine W, Nkengasong JN: Antiretroviral therapy in HIV-2-infected patients: changes in plasma viral load, CD4+ cell counts, and drug resistance profiles of patients treated in Abidjan, Cote d'Ivoire. AIDS 2003:S49-54.

12. Desbois D, Peytavin G, Matheron S, Damond F, Collin G, Bénard A, Campa P, Chêne G, Brun-Vézinet F, Diane Descamps , The French ANRS HIV-2 Cohort (ANRS CO 05 VIH-2): Phenotypic Susceptibility in vitro to Amprenavir, Atazanavir, Darunavir, Lopinavir, and Tipranavir of HIV-2 Clinical Isolates from the French ANRS HIV-2 Cohort [abstract 6 I5]. 14th conference on Retroviruses and opportunistic infections, 25-28 February 2007; Los Angeles, USA

13. McCutchan FE: Global epidemiology of HIV. J Med Virol 2006, 78(Suppl I):S7-SI2.

14. Damond F, Bénard A, on behalf of the ACHleV2e study group: Quality control assessment of HIV-2 viral load quantification assays : Results from an international collaboration on HIV2 infection, 2006 [Abstract 676]. 14th conference on Retroviruses and opportunistic infections, 25-28 February 2007; Los Angeles, USA .

15. Rodés B, Sheldon J, Toro C, Cuevas L, Pérez-Pastrana E, Herrera I, Soriano V: Quantitative detection of plasma human immunodeficiency virus type 2 subtype A RNA by the Nuclisens EasyQ Assay (version I.I). J Clin Microbiol 2007, 45:88-92.

16. Jallow S, Kaye S, Alabi A, Aveika A, Sarge-Njie R, Sabally S, Corrah T, Whittle H, Vanham G, Rowland-Jones S, Janssens W, McConkey SJ: Virological and immunolgical response to Combivir and emergence of drug resistance mutations in a cohort of HIV2 patients in The Gambia. AIDS 2006, 20: |455-I458.

17. Matheron S, Damond F, Benard A, Taieb A, Campa P, Peytavin G, Pueyo S, Brun-Vezinet F, Chene G, ANRS CO5 HIV2 Cohort Study Group: CD4 cell recovery in treated HIV-2 infected adults is lower than expected: results from the French ANRS CO5 HIV-2 cohort. AIDS 2006, 20:459-462.

18. Ndour CT, Batista G, Manga NM, Guèye NF, Badiane NM, Fortez L, Sow PS: Efficacy and tolerance of antiretroviral therapy in HIV-2 infected patients in Dakar: preliminary study. Med Mal Infect 2006, 36: III-II4.

19. van der Ende ME, Prins JM, Brinkman K, Keuter M, Veenstra J, Danner SA, Niesters HG, Osterhaus AD, Schutten M: Clinical, immunological and virological response to different antiretroviral regimens in a cohort of HIV-2-infected patients. AIDS 2003:S55-S6I.

20. Houston SC, Miedzinski LJ, Mashinter LD: Rapid progression of CD4 cell decline and subsequent response to salvage therapy in HIV-2 infection. AIDS 2002, 16:1 189-1191.

21. Mullins C, Eisen G, Popper S, Dieng Sarr A, Sankale JL, Berger J, Wright SB, Chang HR, Coste G, Cooley TP, Rice P, Skolnik PR, Sullivan $M$, Kanki PJ: Highly active antiretroviral therapy and viral response in HIV type $\mathbf{2}$ infection. Clin Infect Dis 2004, 38: $1771-1779$.

22. Macneil A, Sankale JL, Meloni ST, Sarr AD, Mboup S, Kanki P: LongTerm Intrapatient Viral Evolution during HIV-2 Infection. J Infect Dis 2007, 195:726-733. 
23. Pieniazek D, Rayfield $M, H u$ DJ, Nkengasong JN, Soriano V, Heneine W, Zeh C, Agwale SM, Wambebe C, Odama L, Wiktor SZ: HIV-2 protease sequences of subtypes $A$ and $B$ harbor multiple mutations associated with protease inhibitor resistance in HIV-I. AIDS 2004, 18:495-502.

24. Colson P, Henry M, Tivoli N, Gallais H, Gastaut JA, Moreau J, Tamalet $\mathrm{C}$ : Polymorphism and drug-selected mutations in the reverse transcriptase gene of HIV-2 from patients living in southeastern France. J Med Virol 2005, 75:38I-390.

25. BenM'Barek N, Audoly G, Raoult D, Gluschankof P: HIV-2 Protease resistance defined in yeast cells. Retrovirology 2006, 3:58.

26. Damond F, Brun-Vezinet F, Matheron S, Peytavin G, Campa P, Pueyo S, Mammano F, Lastere S, Farfara I, Simon F, Chene G, Descamps D Polymorphism of the human immunodeficiency virus type 2 (HIV-2) protease gene and selection of drug resistance mutations in HIV-2 infected patients treated with protease inhibitors. J Clin Microb 2005, 43:484-487.

27. Colson P, Henry M, Tourres C, Lozachmeur D, Gallais H, Gastaut JA, Moreau J, Tamalet C: Polymorphism and drug-selected mutations in the protease gene of human immunodeficiency virus type 2 from patients living in southern France. J Clin Microb 2004, 42:570-577.

28. Brandin E, Lindborg L, Gyllenstein K, Broström C, Hagberg L, Gisslen $M$, Tuvesson $B$, Blaxhult $A$, Albert $\mathrm{J}$ : pol gene sequence variation in Swedish HIV-2 patients failing antiretroviral therapy. AIDS Res Hum Retrovir 2003, 7:543-550.

29. Damond F, Matheron S, Peytavin G, Campa P, Taieb A, Collin G, Delaunay C, Chêne G, Brun-Vézinet F, Descamps D: Selection of K65R mutation in HIV-2 infected patients receiving tenofovir-containing regimen. Antivir Ther 2004, 9:635-636.

30. Descamps D, Damond F, Matheron S, Collin G, Campa P, Delarue S, Pueyo S, Chêne G, Brun-Vézinet F, French ANRS HIV-2 Cohort Study Group: High frequency of selection of K65R and QI5IM mutations in HIV-2 infected patients receiving nucleoside reverse transcriptase inhibitors containing regimen. J Med Virol 2004, 74: 197-20I.

31. Rodés B, Holguin A, Soriano V, Dourana M, Mansinho K, Antunes F, González-Lahoz J: Emergence of drug resistance mutations in human immunodeficiency virus type 2-infected subjects undergoing antiretroviral therapy. I Clin Microbiol 2000, 38:1370-1374.

32. van der Ende ME, Guillon C, Boers PH, Ly TD, Gruters RA, Osterhaus $A D$, Schutten M: Antiviral resistance of biologic HIV-2 clones obtained from individuals on nucleoside reverse transcriptase inhibitor therapy. I Acquir Immune Defic Syndr 2000, 25: II-I8.

33. Ruelle J, Sanou M, Liu HF, Vandenbroucke AT, Duquenne A, Goubau P: Genetic Polymorphisms and Resistance Mutations of HIV Type 2 in Antiretroviral-Naive Patients in Burkina Faso. AIDS Res Hum Retroviruses 2007, 23:955-964.

34. Ruelle J, Kabamba Mukadi B, Schutten M, Goubau P: Quantitative real-time PCR on Lightcycler ${ }^{\circledR}$ for the detection of human immunodeficiency virus type 2 (HIV-2). J Virol Meth 2004, 17:67-74.

35. Van Kerckhoven I, Fransen K, Peeters M, De Beenhouwer H, Piot P, van der Groen G]: Quantification of human immunodeficiency virus in plasma by RNA PCR, viral culture, and p24 antigen detection. J Clin Microbiol 1994, 32:1669-1673.

36. Ghys PD, Fransen K, Diallo MO, Ettiègne-Traoré V, Coulibaly IM, Yeboué KM, Kalish ML, Maurice C, Whitaker JP, Greenberg AE, Laga $M$ : The associations between cervicovaginal HIV shedding, sexually transmitted diseases and immunosuppression in female sex workers in Abidjan, Cote d'Ivoire. AIDS 1997, I I:F85-93

37. Matheron S, Pueyo S, Damond F, Simon F, Leprêtre A, Campa P, Salamon R, Chêne G, Brun-Vezinet F, French HIV-2 Cohort Study Group: Factors associated with clinical progression in HIV-2 infected-patients: the French ANRS cohort. AIDS 2003, 17:2593-260I.

38. Humphrey JH, Nathoo KJ, Hargrove JW, Iliff PJ, Mutasa KE, Moulton LH, Chidawanyika H, Malaba LC, Zijenah LS, Zvandasara P, Ntozini R, Zunguza CD, Ward B], the ZVITAMBO Study Group: HIV-I and HIV-2 prevalence and associated risk factors among postnatal women in Harare, Zimbabwe. Epidemiol Infect 2007, 135:933-942.
39. Ferns RB, Garson JA: Development and evaluation of a realtime RT-PCR assay for quantification of cell-free human immunodeficiency virus type 2 using a Brome Mosaic Virus internal control. J Virol Methods 2006, 135:102-108.

40. Braun J, Plantier JC, Hellot MF, Tuaillon E, Gueudin M, Damond F, Malmsten A, Corrigan GE, Simon F: A new quantitative HIV load assay based on plasma virion reverse transcriptase activity for the different types, groups and subtypes. AIDS 2003, 17:331-336

4I. Damond F, Gueudin M, Pueyo S, Farfara I, Robertson DL, Descamps $D$, Chène G, Matheron S, Campa P, Brun-Vézinet F, Simon F: Plasma RNA viral load in human immunodeficiency virus type 2 subtype A and subtype B infections. J Clin Microbiol 2002, 40:3654-3659.

42. Schutten M, van den Hoogen B, van der Ende ME, Gruters RA, Osterhaus $A D$, Niesters HG: Development of a real-time quantitative RT-PCR for the detection of HIV-2 RNA in plasma. / Viro Methods 2000, 88:8I-87.

43. Gottlieb GS, Sow PS, Hawes SE, Ndoye I, Redman M, Coll-Seck AM, Faye-Niang MA, Diop A, Kuypers JM, Critchlow CW, Respess R, Mullins Jl, Kiviat NB: Equal plasma viral loads predict a similar rate of CD4+ $T$ cell decline in human immunodeficiency virus (HIV) type I- and HIV-2-infected individuals from Senegal, West Africa. J Infect Dis 2002, 185:905-914.

44. Gustchina A, Weber IT: Comparative analysis of the sequences and structures of HIV-I and HIV-2 proteases. Proteins I99|, 10:325-339.

45. Popper S], Sarr AD, Gueye-Ndiaye A, Mboup S, Essex ME, Kanki PJ: Low plasma human immunodeficiency virus type 2 viral load is independent of proviral load: low virus production in vivo. J Virol 2000, 74: I554-I557.

46. Parreira R, Monteiro F, Padua E, Piedade J, Venenno T, Paixão MT, Esteves A: Natural polymorphisms of HIV type 2 pol sequences from drug-naive individuals. AIDS Res Hum Retroviruses 2006, 22: I I78-II82.

47. Ruelle J, Kabamba Mukadi B, Delferrière N, Goubau P: Selection of resistance mutations in Human Immunodeficiency Virus type 2 (HIV-2) protease and reverse transcriptase [Abstract PE7.8/I]. 10th European AIDS Conference/EACS, 17-20 November 2005, Dublin, Ireland

48. Perach M, Rubinek T, Hizi A: Resistance to nucleoside analogs of selective mutants of human immunodeficiency virus type 2 reverse transcriptase. J Virol 1995, 69:509-5I2.

49. Rodés B, Toro C, Sheldon JA, Jiménez V, Mansinho K, Soriano V: High rate of proV47A selection in patients failing lopinavirbased HAART. AIDS 2006, 20:127-129.

\section{Pre-publication history}

The pre-publication history for this paper can be accessed here:

\section{http://www.biomedcentral.com/1471-2334/8/21/prepub}

Publish with Bio Med Central and every scientist can read your work free of charge

"BioMed Central will be the most significant development for disseminating the results of biomedical research in our lifetime. "

Sir Paul Nurse, Cancer Research UK

Your research papers will be:

- available free of charge to the entire biomedical community

- peer reviewed and published immediately upon acceptance

- cited in PubMed and archived on PubMed Central

- yours - you keep the copyright 